\title{
Development and Application of a Novel Sensitive Immunometric Assay for Calcitonin in a Large Cohort of Patients with Medullary and Differentiated Thyroid Cancer, Thyroid Nodules, and Autoimmune Thyroid Diseases
}

\author{
Cléber P. Camacho ${ }^{a}$ Susan C. Lindsey ${ }^{a}$ Teresa S. Kasamatsu ${ }^{a}$
}

Alberto L. Machado ${ }^{a, b}$ João Roberto M. Martins ${ }^{a}$ Rosa Paula M. Biscolla ${ }^{a} b$

Magnus R. Dias da Silva ${ }^{a}$ José Gilberto H. Vieira ${ }^{a, b}$ Rui M.B. Maciela, b

a Laboratory of Molecular and Translational Endocrinology, Division of Endocrinology, Department of Medicine,



\section{Key Words}

Calcitonin - Medullary thyroid carcinoma - Thyroid nodule . Autoimmune thyroid disease $\cdot$ Immunometric assay

\section{Abstract \\ Background: Serum calcitonin (sCT) is a useful biomarker for medullary thyroid cancer (MTC). Consensus has not been reached concerning $\mathrm{SCT}$ measurements in the evaluation of nodular thyroid disease (NTD). Objective and Methods: We developed a new immunofluorometric assay for SCT and have validated it in samples from 794 patients [203 with MTC, 205 with autoimmune thyroid disease (ATD), 248 with NTD, 80 with differentiated thyroid cancer (DTC) 'free of dis- ease', 58 with chronic renal failure (CRF)] and 178 normal in- dividuals, including samples after pentagastrin tests and samples from the washout of 92 FNA procedures in patients with NTD or MTC. We also compared some samples from pa- tients with low or high calcitonin levels using both this assay and the Nichols Institute Diagnostics (NID) assay. Results: The assay's analytical sensitivity was $1.0 \mathrm{pg} / \mathrm{ml}$. Considering MTC patients prior to surgery, the cut-off values for the $95 \%$}

reference range were $11.1 \mathrm{pg} / \mathrm{ml}$ for males and $5.5 \mathrm{pg} / \mathrm{ml}$ for females and employing the ROC curve were $18.4 \mathrm{pg} / \mathrm{ml}$ for males and $7.8 \mathrm{pg} / \mathrm{ml}$ for females. $\mathrm{SCT}$ in patients with MTC was strongly correlated with disease status. Patients with NTD and ATD did not present false-positive results. SCT measurements were significantly correlated with age (excluding MTC and CRF). The NID test had a strong correlation with our assay. A hook effect was observed only with concentrations $>200,000 \mathrm{pg} / \mathrm{ml}$. Conclusions: We developed a novel sCT assay and validated it in healthy subjects, as well as in a large cohort of patients with MTC, NTD, ATD, DTC, and CRF.

(c) 2014 European Thyroid Association Published by S. Karger AG, Basel

\section{Introduction}

Serum calcitonin (sCT) is a useful biomarker for medullary thyroid cancer (MTC) and is employed for its diagnosis and follow-up monitoring [1]. In addition, some guidelines advocate sCT measurements for the differential diagnosis of nodular thyroid disease (NTD) while

\begin{tabular}{ll}
\hline KARGER & $\begin{array}{l}\text { @ 2014 European Thyroid Association } \\
\text { Published by S. Karger AG, Basel }\end{array}$ \\
E-Mail karger@karger.com & 2235-0640/14/0032-0117\$39.50/0 \\
www.karger.com/etj &
\end{tabular}

Rui M.B. Maciel, MD, PhD

Laboratory of Molecular and Translational Endocrinology, Division of Endocrinology Department of Medicine, Escola Paulista de Medicina, Universidade Federal de São Paulo, Rua Pedro de Toledo 669, 11th Floor, São Paulo, SP 04039-033 (Brazil) E-Mail rui.maciel@ unifesp.br 
other guidelines assume a neutral or a contrary position regarding the use of sCT for NTD due to false-positive results, cost-effectiveness, and large reference range of assays [2-8].

The available sCT immunometric assays present large reference ranges [9-12]. Procalcitonin cross-reactivity in infections, inflammatory reactions and hyperparathyroidism, appears to be minimal [13]. Nevertheless, in other situations, such as autoimmune thyroid diseases (ATD) or chronic renal failure (CRF), the corresponding mild elevations in basal $\mathrm{SCT}$ result in indeterminate results regarding MTC diagnosis [14, 15].

We developed a novel assay because the gold standard assay for measuring sCT is no longer available [10]. Therefore, in this study we have validated a novel immunometric two-site sCT assay in a large cohort of patients, including different clinical scenarios, as MTC and differentiated thyroid cancer (DTC), NTD, ATD, and CRF, besides samples stimulated after the pentagastrin test and from the washout of fine-needle aspiration cytology (FNAC).

\section{Subjects and Methods}

\section{Subjects and Samples}

We collected blood samples from 794 patients (2-84 years old, 617 women and 177 men) and from 178 normal individuals (3-80 years old, 131 women and 47 men) who were followed at the Division of Endocrinology, Department of Medicine, Federal University of São Paulo, in São Paulo, Brazil. A signed letter of informed consent was obtained from all patients or their legal guardians. The study was approved by the Research Ethics Committee of the university.

The patients were: (a) 203 who had MTC before and after surgical treatment, 125 of whom had no evidence of disease after treatment and 68 of whom had elevated sCT prior to or after surgery (with or without evidence of metastasis); (b) 533 who had thyroid disease other than MTC, 205 with ATD, 248 with NTD and 80 with DTC 'free of disease', and (c) 58 who had stable CRF and no evidence of thyroid disease. Additionally, we studied 178 healthy individuals without thyroid disease (no history, normal physical examination, normal thyroid tests and normal neck US).

\section{Samples from Pentagastrin Test}

We performed the pentagastrin test on 45 MTC patients with: (a) positive RET mutations before prophylactic surgery; (b) with persistent detectable sCT levels after surgery, and (c) with NTD with previously high levels of sCT. To perform the pentagastrin test, patients fasted for $8 \mathrm{~h}$, and blood samples were drawn before and 2, 5, 10 and $15 \mathrm{~min}$ after an intravenous bolus of $0.5 \mathrm{~g} / \mathrm{kg}$ pentagastrin (Pentagastrin ${ }^{\mathrm{TM}}$; Cambridge Laboratories Ltd, Newcastle, UK) [16]. All 225 samples derived from these tests were centrifuged, and serum aliquots were stored at $-20^{\circ} \mathrm{C}$ until sCT measurements.

\section{Samples from FNAC Washout}

FNAC procedures were performed in patients with NTD or in lymph nodes of MTC patients, yielding a total of 92 samples for $\mathrm{CT}$ analysis from the FNAC washouts. After the smear was prepared for cytology, the needle was washed with $1 \mathrm{ml}$ of $0.9 \% \mathrm{NaCl}$, and the sample was stored at $-20^{\circ} \mathrm{C}$ until the CT measurements.

\section{Calcitonin Assay}

The immunofluorometric two-site assay is based on the binding of human calcitonin by monoclonal antibodies (mAbs) obtained from hybridomas produced from spleen cells of mice that had been immunized with calcitonin peptides $[17,18]$. Screening (using human calcitonin at $>97 \%$ purity; Scripps Laboratories, San Diego, Calif., USA), selection, ascites production, purification and IgG subtyping were previously described [19]. After titer and specificity analysis, we selected two cell lines, one specific for amino acids 11-23 and the other specific for amino acids 17-32.

The assay is based on the first $\mathrm{mAb}$ bound to the wells of the microtiter plates to serve as the solid phase, and the second $\mathrm{mAb}$ biotinylated (Sulfo-NHS-LC-Biotin Kit; Pierce, Rockford, Ill., USA). Microtiter plates were coated with the first $\mathrm{mAb}$ in PBS at a final concentration of $10 \mu \mathrm{g} / \mathrm{ml}$, by adding $200 \mu \mathrm{l}$ to each well and letting them incubate overnight at $4{ }^{\circ} \mathrm{C}$. Next, the plate was washed and blocked with buffer ( $50 \mathrm{mM}$ Tris $\mathrm{pH} 7.75,0.5 \%$ BSA and $0.05 \%$ bovine $\gamma$-globulin) at $37^{\circ} \mathrm{C}$ for $1 \mathrm{~h}$. The standard curve was based on the WHO International Standard Calcitonin, Human NIBSC $89 / 620$ prepared by serial dilution in human serum undetectable for sCT. After washing the plate, $150 \mu \mathrm{l}$ of the standard curve, or controls, or samples were added. Next, $50 \mu$ of the biotinylated second $\mathrm{mAb}(1 / 3,000)$ was added, supplemented with $5 \%$ mouse serum. The plate was shaken for $1 \mathrm{~h}$ at room temperature in the dark and then incubated for $18 \mathrm{~h}$ at $4^{\circ} \mathrm{C}$. After washing, we added $200 \mu \mathrm{l}$ of europium-labeled streptavidin $(1 / 2,000)$ (PerkinElmer, USA) to each well and incubated the plate for $30 \mathrm{~min}$ at room temperature with agitation before washing and adding enhancing solution for time-resolved fluorescence reading.

\section{Comparative Analysis}

We compared the samples from 23 patients with low or high calcitonin levels using both our novel assay and the Nichols Institute Diagnostics (NID) sCT assay.

\section{Statistical Analysis}

The results are presented as frequencies with the median, minimum and maximum values. The $95 \%$ confidence interval was calculated after log transformation of the data, and the final results were back-transformed to the original scale [19]. The cut-off value was calculated using the ROC curve statistical approach. Spearman's correlations were calculated, and the two-group analysis for gender was performed using the Mann-Whitney $U$ test. The data were analyzed using SPSS 13 for Windows (SPSS, Inc., Chicago, Ill., USA). A p value of 0.05 was considered significant.

\section{Results}

We present a novel method to quantify CT levels that was utilized to assay and validate 1,289 samples (972 basal serum samples from patients and healthy individuals, 


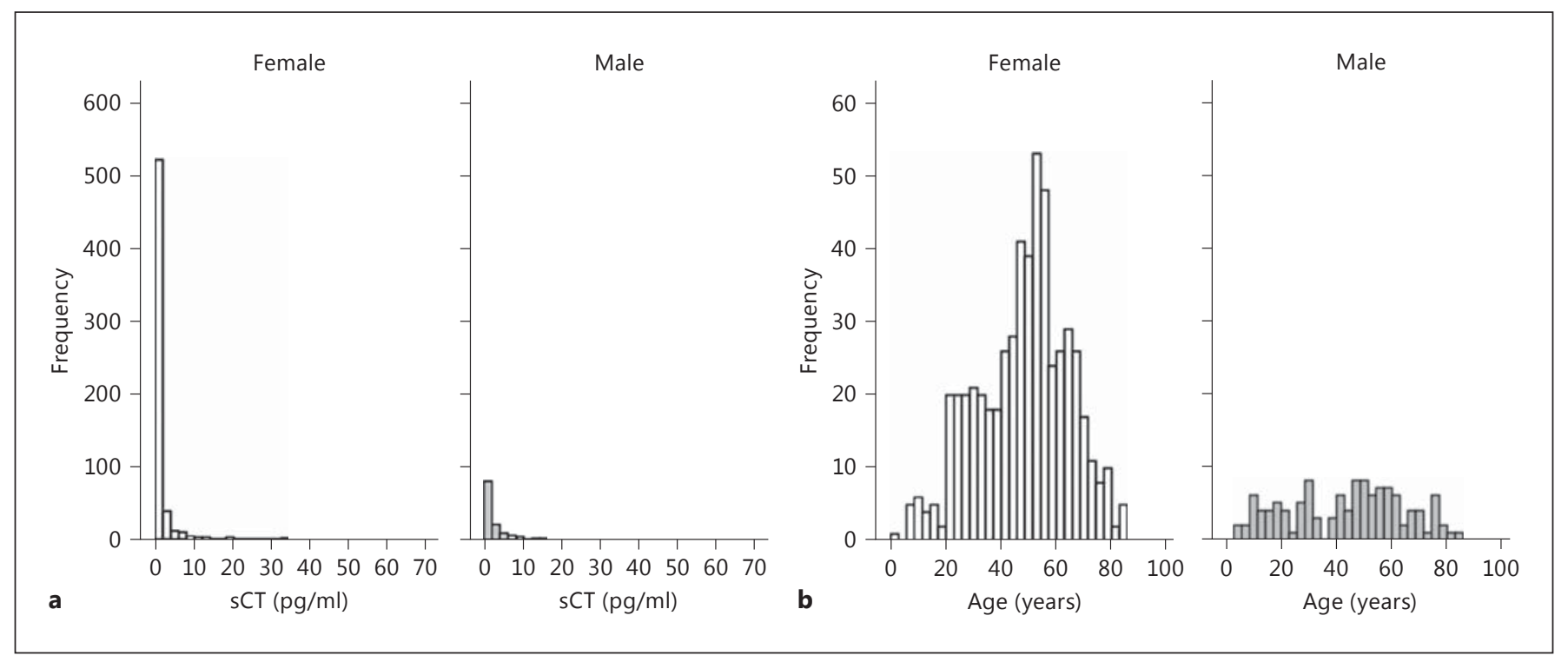

Fig. 1. a Histogram of $\mathrm{sCT}(\mathrm{pg} / \mathrm{ml})$ measurements in female and male individuals without MTC or CRF. b Age histogram of female and male individuals without MTC or CRF. c Bar graph with median sCT ( pg/ml) on the vertical axis and age on the horizontal axis in female (white bars) and male (black bars) individuals without MTC or CRF.

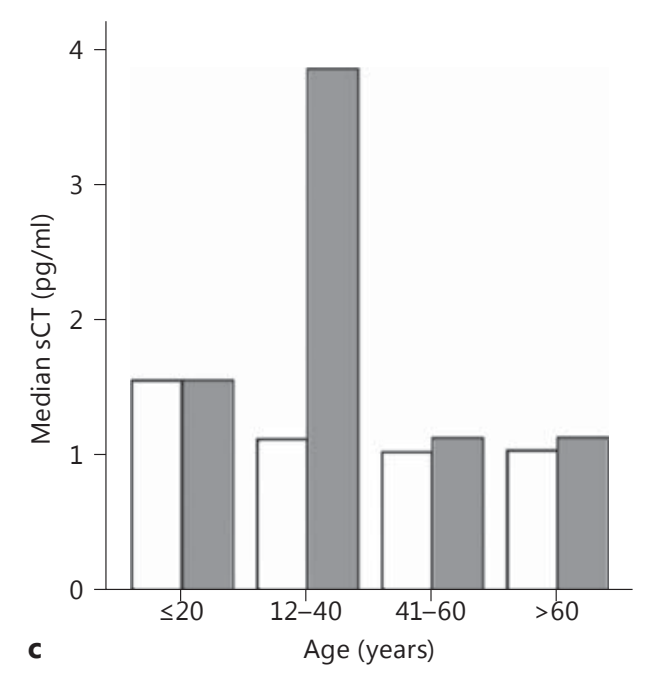

225 stimulated serum samples from pentagastrin tests, and 92 samples from FNAC washouts).

The analytical sensitivity of the assay is $1.0 \mathrm{pg} / \mathrm{ml}$, with an intra-assay coefficient of variation of $2.1-6.4 \%$ and an inter-assay coefficient of variation of 7.1-9.4\%. In normal male subjects, $97.9 \%$ exhibited sCT levels $<18.4 \mathrm{pg} / \mathrm{ml}$, and $91.6 \%$ of the normal female subjects presented with sCT levels $<7.8 \mathrm{pg} / \mathrm{ml}$ (fig. 1a; tables $1-4$ ). The $95 \%$ reference range value for the entire cohort was $6.9 \mathrm{pg} / \mathrm{ml}$, with a cut-off value of $9.9 \mathrm{pg} / \mathrm{ml}$ within the ROC curve. When we analyzed the male and female groups separately, the $95 \%$ reference interval values were 11.1 and $5.5 \mathrm{pg} / \mathrm{ml}$, respectively. Considering MTC patients prior to surgery

and the use of the ROC curve, the cut-off value for the male group was 18.4 and $7.8 \mathrm{pg} / \mathrm{ml}$ for the female group (fig. 2; tables 1-4).

Patients with NTD exhibited a maximum sCT concentration of $15.6 \mathrm{pg} / \mathrm{ml}$ in males with a median of $1.0 \mathrm{pg} / \mathrm{ml}$. All the male patients had levels $<18.4 \mathrm{pg} / \mathrm{ml}$, and $99.1 \%$ of the female patients had sCT concentrations $\leq 7.8 \mathrm{pg} / \mathrm{ml}$ (tables 1-4).

Patients with ATD exhibited a minimum sCT concentration of $1.0 \mathrm{pg} / \mathrm{ml}$, a maximum of $15.1 \mathrm{pg} / \mathrm{ml}$, and a median of $1.0 \mathrm{pg} / \mathrm{ml}$. Among ATD patients, $100 \%$ of the males presented with levels $<18.4 \mathrm{pg} / \mathrm{ml}$, and $98.8 \%$ of the females demonstrated levels $<7.8 \mathrm{pg} / \mathrm{ml}$ (tables 1-4). 
Table 1. Minimal, maximal and median CT values (in $\mathrm{pg} / \mathrm{ml}$ ) and total number of subjects analyzed for normal subjects and patients with NTD, ATD, CRF, and DTC

\begin{tabular}{|c|c|c|c|c|}
\hline & Min & Max & Med & Tota \\
\hline \multicolumn{5}{|c|}{ Normal subjects } \\
\hline Male & 1.0 & 19.8 & 2.4 & 47 \\
\hline Female & 1.0 & 33.0 & 1.0 & 131 \\
\hline Total & 1.0 & 33.0 & 1.4 & 178 \\
\hline \multicolumn{5}{|c|}{ NTD patients } \\
\hline Male & 1.0 & 15.6 & 1.0 & 22 \\
\hline Female & 1.0 & 12.7 & 1.0 & 226 \\
\hline Total & 1.0 & 64.0 & 1.0 & 248 \\
\hline \multicolumn{5}{|c|}{ ATD patients } \\
\hline Male & 1.0 & 5.0 & 1.0 & 44 \\
\hline Female & 1.0 & 15.1 & 1.0 & 161 \\
\hline Total & 1.0 & 15.1 & 1.0 & 205 \\
\hline \multicolumn{5}{|c|}{ CRF patients } \\
\hline Male & 1.0 & 21.7 & 1.9 & 25 \\
\hline Female & 1.0 & 18.4 & 1.0 & 33 \\
\hline Total & 1.0 & 21.7 & 1.0 & 58 \\
\hline \multicolumn{5}{|c|}{ DTC patients } \\
\hline Male & 1.0 & 6.3 & 1.0 & 11 \\
\hline Female & 1.0 & 9.1 & 1.0 & 69 \\
\hline Total & 1.0 & 9.1 & 1.0 & 80 \\
\hline
\end{tabular}

Patients with DTC were considered as a negative control group, since they were submitted to total thyroidectomy, were 'free of disease' and, therefore, were expected to have undetectable sCT values. However, 9 out of 80 patients displayed sCT levels between 1 and $10 \mathrm{pg} / \mathrm{ml}$ (table 2). The maximum value observed in this group was $9.1 \mathrm{pg} / \mathrm{ml}$ (tables $1-4)$.

The patients with stable CRF had a minimum sCT concentration of $1.0 \mathrm{pg} / \mathrm{ml}$, a maximum of $21.7 \mathrm{pg} / \mathrm{ml}$, and a median of $3.2 \mathrm{pg} / \mathrm{ml}$ (tables $1-4$ ). In this group, $92 \%$ of the male patients presented with levels $\leq 18.4 \mathrm{pg} / \mathrm{ml}$, and $93.9 \%$ of the female patients demonstrated levels $<7.8$ $\mathrm{pg} / \mathrm{ml}$.

All of the sCT measurements, excluding those from the MTC and CRF patients, were significantly correlated with age ( $r s-0.225, p=0.01$ ). The age histogram displays the higher concentration of individuals between 40 and 60 years (fig. 1b). The highest median value in women was observed in those patients $<20$ years of age, whereas the highest median value in men was observed in the 20- to 40 -year-old age group (fig. 1c). The highest absolute values occurred in female patients $<20$ years of age and male patients between 40 and 60 years of age.
Table 2. Number and percentage (in parentheses) of normal male subjects and male patients with NTD, ATD, CRF, and DTC with undetectable values, under the $95 \%$ reference range $(11.1 \mathrm{pg} / \mathrm{ml})$ and the ROC curve cut-off $(18.4 \mathrm{pg} / \mathrm{ml})$

\begin{tabular}{lrll}
\hline & $\leq 1 \mathrm{pg} / \mathrm{ml}$ & $\leq 11.1 \mathrm{pg} / \mathrm{ml}$ & $\leq 18.4 \mathrm{pg} / \mathrm{ml}$ \\
\hline Male subjects only & & & \\
Normal subjects & $11(23.4)$ & $43(91.5)$ & $47(100)$ \\
NTD patients & $12(52.2)$ & $21(91.3)$ & $22(100)$ \\
ATD patients & $34(75.6)$ & $44(100)$ & $44(100)$ \\
CRF patients & $7(28.0)$ & $22(88)$ & $23(92)$ \\
DTC patients & $7(63.6)$ & $11(100)$ & $11(100)$ \\
\hline
\end{tabular}

Table 3. Number and percentage (in parentheses) of normal female subjects and female patients with NTD, ATD, CRF, and DTC with undetectable values under the $95 \%$ reference range $(5.5 \mathrm{pg} /$ $\mathrm{ml})$ and the ROC curve cut-off $(7.8 \mathrm{pg} / \mathrm{ml})$

\begin{tabular}{lrrr}
\hline & $\leq 1 \mathrm{pg} / \mathrm{ml}$ & $\leq 5.5 \mathrm{pg} / \mathrm{ml}$ & \multicolumn{1}{l}{$\leq 7.8 \mathrm{pg} / \mathrm{ml}$} \\
\hline \multicolumn{4}{l}{ Female subjects only } \\
Normal subjects & $69(52.3)$ & $112(85.5)$ & $120(91.6)$ \\
NTD patients & $200(88.5)$ & $222(98.7)$ & $223(99.1)$ \\
ATD patients & $140(87.5)$ & $159(98.8)$ & $159(98.8)$ \\
CRF patients & $26(76.5)$ & $31(93.9)$ & $31(93.9)$ \\
DTC patients & $64(92.8)$ & $66(95.7)$ & $68(98.6)$ \\
\hline
\end{tabular}

Table 4. Number and percentage (in parentheses) of normal subjects and patients with NTD, ATD, CRF, and DTC without gender discrimination with undetectable values, values under the $95 \%$ reference range $(6.9 \mathrm{pg} / \mathrm{ml})$ and the ROC curve cut-off $(9.9 \mathrm{pg} / \mathrm{ml})$

\begin{tabular}{lrrr}
\hline & $\leq 1 \mathrm{pg} / \mathrm{ml}$ & $\leq 6.9 \mathrm{pg} / \mathrm{ml}$ & $\leq 9.9 \mathrm{pg} / \mathrm{ml}$ \\
\hline All subjects & & & \\
Normal subjects & $69(52.3)$ & $155(87.0)$ & $165(92.7)$ \\
NTD patients & $200(88.5)$ & $242(97.6)$ & $246(99.2)$ \\
ATD patients & $140(87.5)$ & $203(99.0)$ & $203(99.0)$ \\
CRF patients & $26(76.5)$ & $51(87.9)$ & $53(91.4)$ \\
DTC patients & $64(92.8)$ & $78(97.5)$ & $80(100)$ \\
\hline
\end{tabular}

The NID test utilized capture antibodies against protein regions similar to those employed in our assay. Therefore, when the same samples were analyzed using our assay and the NID test system, we identified a strong correlation between results (fig. 3 ).

We also analyzed samples from 45 patients who underwent a pentagastrin stimulation test, 29 of whom car- 

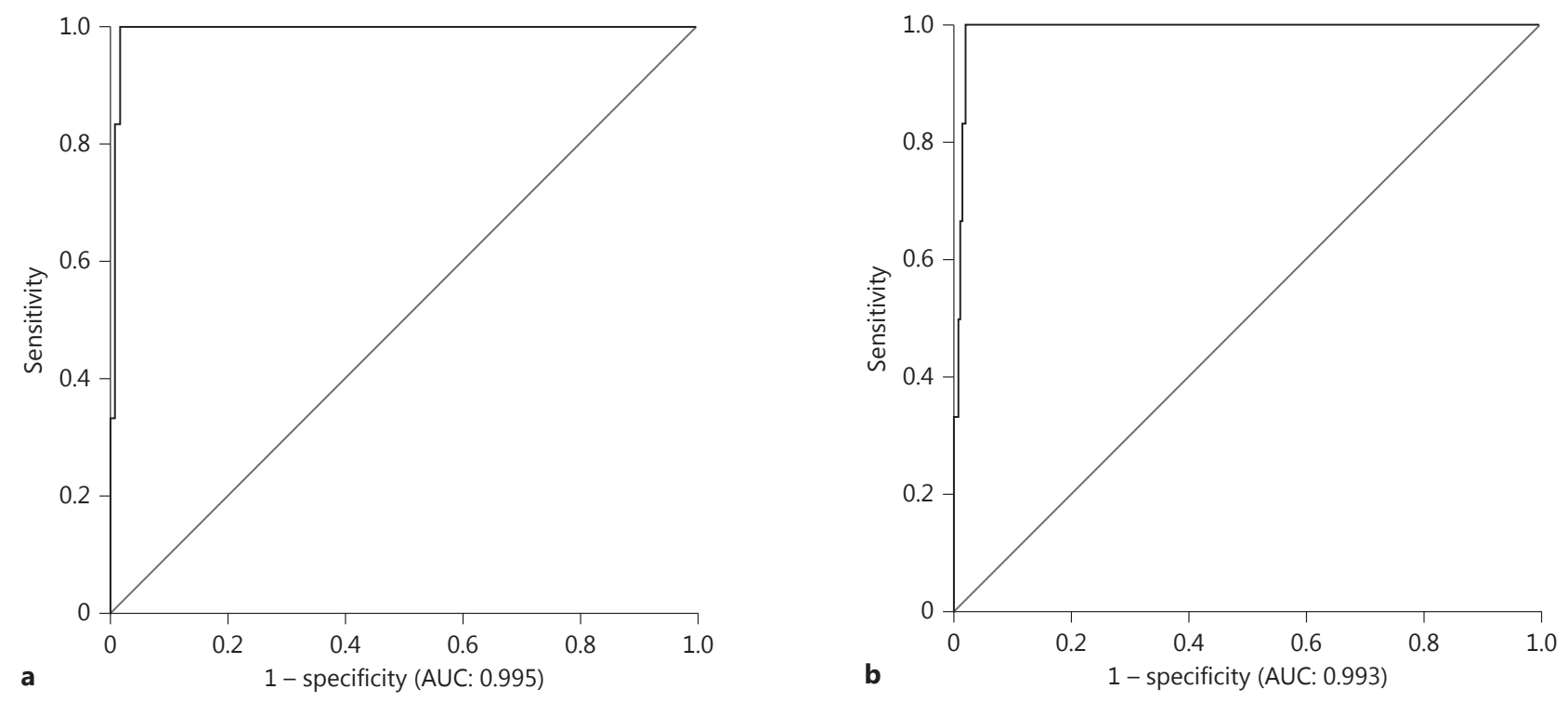

Fig. 2. ROC curve of the male (a) and female (b) group, to identify the cut-off level for sCT with the highest accuracy to differentiate between individuals without and with MTC. AUC = Area under the curve.

ried a RET mutation prior to thyroidectomy, 12 of whom had undergone thyroidectomy for MTC treatment, and 4 of whom were suspected to harbor MTC. The maximum sCT concentration that was observed after pentagastrin stimulation was $784 \mathrm{pg} / \mathrm{ml}$. After stimulation, a threefold increase in the basal calcitonin value or an sCT concentration $>100 \mathrm{pg} / \mathrm{ml}$ was considered a positive response; based on these criteria, 22 of the 45 patients were positive for the pentagastrin stimulation test (12 mutation carriers, 7 MTC patients post-surgery, and 3 patients with suspected MTC). The 7 RET mutation carriers underwent thyroidectomy, and the histology was confirmed to be either MTC or C-cell hyperplasia. There were 23 subjects who did not respond to the stimulation test, but this result was compatible with the results of the clinical follow-up.

All of the FNAC washout samples were diluted prior to analysis to avoid the hook effect. Calcitonin levels were measured in 50 lymph nodes; the minimum observed level of $1.0 \mathrm{pg} / \mathrm{ml}$ was identified in a lymph node with benign cytological findings, whereas the maximum concentration of 3,875,000 $\mathrm{pg} / \mathrm{ml}$ occurred in a metastatic lymph node from a patient with MTC. None of the benign lymph nodes exhibited calcitonin levels $>1.0 \mathrm{pg} / \mathrm{ml}$. Additionally, 5 of the 9 cases with values $>1,638 \mathrm{pg} / \mathrm{ml}$ were from samples that were non-diagnostic or unsatisfactory by cytological determination. To calculate the cut-off value for

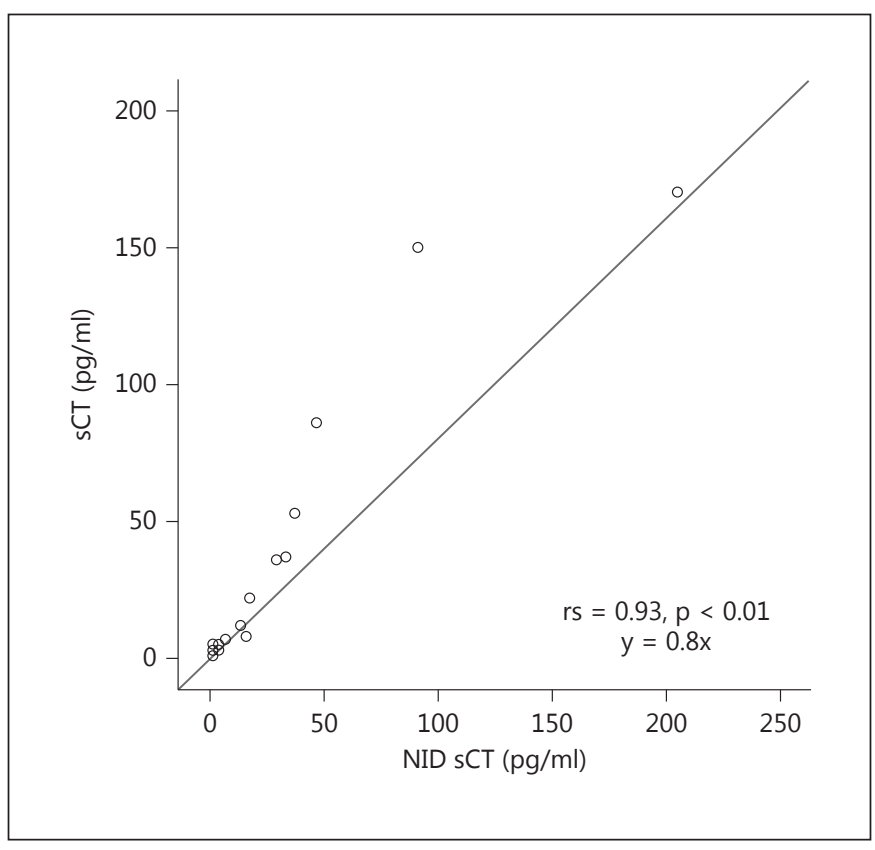

Fig. 3. Correlation between the measurement of sCT $(\mathrm{pg} / \mathrm{ml})$ in 23 samples with our assay (vertical axis) and with the NID test system (horizontal axis). 
FNAC washouts, we use 37 washouts with positive or negative cytological results through a ROC curve. The cut-off for a positive metastatic lymph node was $270 \mathrm{pg} /$ $\mathrm{ml}$. All of the 11 positive metastatic samples had CT levels $>558 \mathrm{pg} / \mathrm{ml}$, and, by investigating these positive lymph node FNAC washouts, we were able to estimate that $200,000 \mathrm{pg} / \mathrm{ml}$ is the concentration of calcitonin at which a hook effect may be observed.

In the 42 washouts performed on thyroid nodules, 6 subjects with benign cytology had calcitonin concentrations $<2.2 \mathrm{pg} / \mathrm{ml}$, and 4 of the 6 subjects with calcitonin levels $>1,600 \mathrm{pg} / \mathrm{ml}$ were positive by cytology for malignant disease. There were also 2 patients with positive cytology who presented with washout calcitonin concentrations of 2.1 and $2.7 \mathrm{pg} / \mathrm{ml}$, but the surgical pathology reports did not confirm the diagnosis of MTC suggested by the FNA. Furthermore, 1 of the 8 samples that were insufficient for or indeterminate by cytological analysis displayed a washout calcitonin concentration of 2,076 pg/ $\mathrm{ml}$, with a surgical pathology report confirming MTC.

\section{Discussion}

Since immunoassays were developed, the detection of biological substances has become less time-consuming, more sensitive and more specific [20]. Our single-step, two-site assay utilizing mAbs was designed to obtain maximum sensitivity and specificity without interference or cross-reactivity.

When validating and determining the reference range for a new assay, it is necessary to evaluate both healthy and unhealthy populations. Although we selected a healthy group to determine normal sCT levels and to compare these levels with those of MTC patients, we believe that the most important problem facing our daily practice is the application of sCT measurements to exclude the presence of MTC in patients with NTD and ATD. Furthermore, the sCT concentration can be quantitated in patients for whom MTC is not suspected, i.e. in patients with diabetes mellitus type 2 or in non-obese subjects treated with the human glucagon-like peptide-1 (GLP-1) analog liraglutide. Because the GLP-1 receptor agonist has been associated with increased sCT levels and tumor formation in rodents, the $\mathrm{SCT}$ concentration has been analyzed in over 5,000 patients who were receiving either liraglutide or control therapy, but an effect of the GLP-1 analog on sCT levels was not demonstrated [21].

Previous reports have shown significant differences in sCT levels between male and female subjects [2, 22-24], which is in accordance with our results. A post-mortem study has shown that physiologically, men have twice as many C cells as women [25]. Additionally, the reference ranges for the NID assay account for gender differences, with values that are comparable to ours $(<11.5 \mathrm{ng} / \mathrm{l}$ for men and $<4.6 \mathrm{ng} / \mathrm{l}$ for women) [22]. The age of the patient is another complicating factor, and the negative correlation between sCT levels and age that was observed in our study is supported by studies demonstrating higher levels of sCT in children than in adults $[2,22,24]$.

In spite of several reports suggesting the routine measurement of sCT in the evaluation of thyroid nodules [2, $4,5,26-30]$, there is some resistance in adopting this approach because of concerns regarding false-positive results $[6,29,30]$. However, in this study, we demonstrated that $100 \%$ of the male NTD patients without MTC and more than $99 \%$ of the female NTD patients without MTC presented with sCT levels below the calculated cut-off for their respective groups $(\leq 18.4$ and $\leq 7.8 \mathrm{pg} / \mathrm{ml}$, respectively). In the ATD group, $100 \%$ of the male patients and $98.8 \%$ of the female patients exhibited sCT concentrations below the respective cut-off values.

Other area of resistance for the routine use of $\mathrm{sCT}$ measurements in the evaluation of NTD is related to costeffectiveness. However, after the convincing study by Cheung et al. [31], who performed sensitivity analyses and found the cost-effectiveness of calcitonin screening to be effective and very similar to other screening strategies, as TSH, colonoscopy, and mammography screening, it is becoming clear that this issue was also answered. In this regard, our assay was developed in house and some of the costs, as personnel and the development of monoclonals, were included in the research proposal. The calculated cost for its determination is USD 5.00 per sample.

Only a few studies of sCT screening for MTC in NTD have included CRF patients $[3,14,31,32]$. Among the patients at our center with stable kidney disease, less than $4 \%$ of the males and $6.1 \%$ of the females demonstrated sCT levels above the cut-off for each group, which is similar to a previous study [14]. However, another study has shown that the prevalence of hypercalcitoninemia in dialysis patients amounts to $46 \%$ and that it is more common in male than in female patients [31]; this group has also demonstrated a reversibility of hypercalcitoninemia after kidney transplantation [32]. In a recent paper, Kratzsch et al. [10] have shown that higher CRF stages were associated with increased sCT concentrations, but many of these patients were also treated with proton pump inhibitor therapy, a clinical condition known to be associated with hypercalcitoninemia. Thus, we believe that different results would 
be observed in our study if unstable CRF patients undergoing hemodialysis were included.

In the DTC-treated group, where we expected to have undetectable sCT levels, we detected a low sCT concentration in 9/80 patients. Other studies have also detected sCT in DTC patients, but the results were interpreted as related to cross-reactivity with non-thyroid substances [10]. Nevertheless, patients who have undergone a total thyroidectomy and radioiodine therapy are not necessarily completely free of thyroid tissue because ablation failure may occur in nearly $25 \%$ of these cases [33]. Therefore, these findings suggest that low sCT levels may also be detected in MTC patients after surgery, due to remnant normal thyroid tissue, containing normal $\mathrm{C}$ cells, even in the absence of a tumor, as previously suggested [3].

To evaluate the occurrence of the hook effect, we measured the high sCT values from the pentagastrin stimulation tests, as well as those in the FNA washouts. We observed the hook effect in samples with high calcitonin values from the FNA washouts but not in those from the pentagastrin test. Thus, we now routinely dilute samples from FNA washouts before analysis [34].

Another concern is the prevalence of interference in calcitonin assays stemming from heterophilic antibodies in the blood samples, which was reported to occur $3.7 \%$ of the time [35]. This type of interference is relevant to laboratory practice, and the addition of mouse serum could potentially prevent misleading results. As such, when we suspected a false-positive result (due to a discrepancy between the clinical and the laboratory findings), we first repeated the assay on a new sample to rule out pre-analytical errors. If the high level was reproduced, we diluted the sample with mouse serum; if the value then decreased in a non-linear manner, interference by heterophilic antibodies was suspected [36].

We also utilized our assay to measure calcitonin levels in FNAC washout samples from thyroid nodules and lymph nodes. The concentration of CT in the FNAC washout samples was more accurate than the cytology results, and our assay was particularly useful for samples with non-diagnostic or unsatisfactory material for or yielding indeterminate results by cytology.

In conclusion, we developed and validated a novel CT assay, using it in healthy subjects, as well as in a large cohort of patients with MTC, DTC, NTD, ATD and CRF. We established cut-off values, one based on the $95 \%$ reference range $(11.1 \mathrm{pg} / \mathrm{ml}$ for males vs. $5.5 \mathrm{pg} / \mathrm{ml}$ for females) and the other on the ROC curve $(18.4 \mathrm{pg} / \mathrm{ml}$ for males vs. $7.8 \mathrm{pg} / \mathrm{ml}$ for females). Our results have confirmed previous data showing higher values in children, as well as in adult males, compared with adult females. Furthermore, this study has suggested that SCT can be used as a screening for MTC in patients with NTD, as well as in patients with ATD, since the large majority of patients with these diseases have shown values below the reference ranges. This new assay is also very useful for elevated values of $\mathrm{sCT}$, as in stimulation tests and in washout samples from FNAC. In addition, we demonstrated a strong correlation between our assay and the NID assay, which was previously utilized worldwide. Therefore, this new assay has been validated.

\section{Acknowledgements}

This work was supported by research grants from the São Paulo State Research Foundation-FAPESP to R.M.B.M. and to M.R.D.S. (2006/60402-1 and 2010/51547-1) and by a FAPESP Fellowship Grant to S.C.L. (2009/50575-4). R.M.B.M. is investigator of the Brazilian Research Council; R.P.M.B., J.G.H.V. and R.M.B.M. are also investigators of the Fleury Group. The authors are very grateful to Dr. M. Conceição Mamone for her expertise in thyroid cytopathology, to the Medullary Thyroid Carcinoma Study Group, Drs. Flavia Valente, Ji H. Hiang, Fausto Germano-Neto, Priscila Signorini, Rosana Delcelo, Janete Cerutti, Mariana Frossard, Mariana N. L. Oliveira, Ilda S. Kunii, Sharmila Sousa and Ana O. Hoff for their helpful suggestions and information about patients and to Angela M. Faria and Yeda Queiroga for their efficient laboratory administration. We are very grateful to the Head and Neck Surgical Team, particularly Drs. Flavio C. Hojaij, Marcel Palumbo and Fabio Brodskyn.

\section{Disclosure Statement}

The authors have no conflicts of interest to disclose.

References
1 Kloos RT, Eng C, Evans DB, Francis GL, Gagel RF, Gharib H, Moley JF, Pacini F, Ringel MD, Schlumberger M, Wells SA Jr: Medullary thyroid cancer: management guidelines of the American Thyroid Association. Thyroid 2009;19:565-612.

-2 Pacini F, Schlumberger M, Dralle H, Elisei R, Smit JW, Wiersinga W: European consensus for the management of patients with differentiated thyroid carcinoma of the follicular epithelium. Eur J Endocrinol 2006;154:787-803.

-3 Gharib H, Papini E, Paschke R, Duick DS, Valcavi R, Hegedus L, Vitti P: American Association of Clinical Endocrinologists, Associazione Medici Endocrinologi, and European Thyroid Association Medical guidelines for clinical practice for the diagnosis and management of thyroid nodules: executive summary of recommendations. Endocr Pract 2010;16:468-475.
Serum Calcitonin Measurement Using a

Novel Immunometric Assay
DOI: $10.1159 / 000363055$ 
4 Cooper DS, Doherty GM, Haugen BR, Kloos RT, Lee SL, Mandel SJ, Mazzaferri EL, McIver B, Pacini F, Schlumberger M, Sherman SI, Steward DL, Tuttle RM: Revised American Thyroid Association management guidelines for patients with thyroid nodules and differentiated thyroid cancer. Thyroid 2009;19: 1167-1214.

-5 Sherman SI, Angelos P, Ball DW, Byrd D, Clark OH, Daniels GH, Dilawari RA, Ehya H, Farrar WB, Gagel RF, Kandeel F, Kloos RT, Kopp P, Lamonica DM, Loree TR, Lydiatt WM, McCaffrey J, Olson JA Jr, Ridge JA, Shah JP, Sisson JC, Tuttle RM, Urist MM: Thyroid carcinoma. J Natl Compr Canc Netw 2007;5:568-621.

-6 Chen H, Sippel RS, O'Dorisio MS, Vinik AI, Lloyd RV, Pacak K: The North American Neuroendocrine Tumor Society consensus guideline for the diagnosis and management of neuroendocrine tumors: pheochromocytoma, paraganglioma, and medullary thyroid cancer. Pancreas 2010;39:775-783.

7 Huang T-W, Lai J-H, Wu M-Y, Chen S-L, Wu C-H, Tam K-W: Systematic review of clinical practice guidelines in the diagnosis and management of thyroid nodules and cancer. BMC Med 2013;11:191-201.

8 Rosario PW, Ward LS, Carvalho GA, Graf H, Maciel RMB, Maciel LM, Maia AL, Vaisman M. Thyroid nodules and differentiated thyroid cancer: update on the Brazilian consensus. Arq Brasil Endocrinol Metab 2013;57:240-264.

$\checkmark 9$ D'Herbomez M, Caron P, Bauters C, Do Cao C, Schlienger J-L, Sapin R, Baldet L, Carnaille $B$, Wémeau J-L: Reference range of serum calcitonin levels in humans: influence of calcitonin assays, sex, age, and cigarette smoking. Eur J Endocrinol 2007;157:749-755.

$\checkmark 10$ Kratzsch J, Petzold A, Raue F, Reinhardt W, Brocker-Preuss M, Gorges R, Mann K, Karges W, Morghenthaler N, Luster M, Reiners C, Thiery J, Dralle H, Fuhrer D: Basal and stimulated calcitonin and procalcitonin by various assays in patients with and without medullary thyroid cancer. Clin Chem 2011;57:467-474.

-11 Motte P, Vauzelle P, Gardet P, Ghillani P, Caillou B, Parmentier C, Bohuon C, Bellet D: Construction and clinical validation of a sensitive and specific assay for serum mature calcitonin using monoclonal anti-peptide antibodies. Clin Chim Acta 1988;174:35-54.

$\checkmark 12$ Bieglmayer C, Vierhapper H, Dudczak R, Niederle B: Measurement of calcitonin by immunoassay analyzers. Clin Chem Lab Med 2007;45:662-666.
13 Tommasi M, Raspanti S: Comparison of calcitonin determinations by polyclonal and monoclonal IRMAs. Clin Chem 2007;53: 798-799.

14 Martinetti A, Seregni E, Ferrari L, Pallotti F, Aliberti G, Coliva A, Fracassi S, Bombardieri E: Evaluation of circulating calcitonin: analytical aspects. Tumori 2003;89:566-568.

15 Niccoli P, Brunet P, Roubicek C, Roux F, Baudin E, Lejeune PJ, Berland Y, Conte-Devolx B: Abnormal calcitonin basal levels and pentagastrin response in patients with chronic renal failure on maintenance hemodialysis. Eur J Endocrinol 1995;132:75-81.

16 Hauache OM, Vieira JGH, Maciel RMB: Laboratory diagnosis of medullary thyroid carcinoma: basal calcitonin and stimulatory tests. Arq Bras Endocrinol Metab 2003;47:529-533.

17 Goding JW: Antibody production by hybridomas. J Immunol Methods 1980;39:285-308.

18 Pereira AB, Nishida SK, Vieira JGH, Lombardi MT, Silva MS, Ajzen H, Ramos OL: Monoclonal antibody-based immunoenzymometric assays of retinol-binding protein. Clin Chem 1993;39:472-476.

19 Vieira JGH, Lombardi MT, Nishida SK: Monoclonal antibody-based immune-enzymometric assay for serum human growth hormone. Braz J Med Biol Res 1990;23:293-296.

20 Horn PS, Pesce AJ: Reference intervals: an update. Clin Chim Acta 2003;334:5-23.

21 Weissel M, Kainz H, Tyl E, Ogunyemi E, Woloszczuk W: Clinical evaluation of new assays for determination of serum calcitonin concentrations. Acta Endocrinol (Copenh) 1991; 124:540-544.

22 Hegedus L, Moses AC, Zdravkovic M, Le Thi T, Daniels GH: GLP-1 and calcitonin concentration in humans: lack of evidence of calcitonin release from sequential screening in over 5,000 subjects with type 2 diabetes or nondiabetic obese subjects treated with the human GLP-1 analog, liraglutide. J Clin Endocrinol Metab 2011;96:853-860.

23 Basuyau JP, Mallet E, Leroy M, Brunelle P: Reference intervals for serum calcitonin in men, women, and children. Clin Chem 2004; 50:1828-1830.

24 Verga U, Morpurgo PS, Vaghi I, Radetti G, Beck-Peccoz P: Normal range of calcitonin in children measured by a chemiluminescent two-site immunometric assay. Horm Res 2006;66:17-20.

25 Suzuki H: Calcitonin levels in normal individuals with new highly sensitive chemiluminescent enzyme immunoassay. J Clin Lab Anal 1988;12:218-222.

-26 Guyetant S, Rousselet MC, Durigon M, Cheppard D, Franc B, Guerin O, Saint-Andre JP: Sex-related C-cell hyperplasia in the normal human thyroid: a quantitative autopsy study. J Clin Endocrinol Metab 1997;82:42-47.
27 Elisei R, Bottici V, Luchetti F, Di Coscio G, Romei C, Grasso L, Miccoli P, Iacconi P, Basolo F, Pinchera A, Pacini F: Impact of routine measurement of serum calcitonin on the diagnosis and outcome of medullary thyroid cancer: experience in 10,864 patients with nodular thyroid disorders. J Clin Endocrinol Metab 2004;89:163-168.

28 Vierhapper H, Niederle B, Bieglmayer C, Kasere K, Baumgartner-Parzer S: Early diagnosis and curative therapy of medullary thyroid carcinoma by routine measurement of serum calcitonin in patients with thyroid disorders Thyroid 2005;15:1267-1272.

29 Papi G, Corsello SM, Cioni K, Pizzini AM, Corrado S, Carapezzi C, Fadda G, Baldini A, Carani C, Pontecorvi A, Roti E: Value of routine measurement of serum calcitonin concentrations in patients with nodular thyroid disease: a multicenter study. J Endocrinol Invest 2006;29:427-437.

30 Elisei R: Routine serum calcitonin measurement in the evaluation of thyroid nodules. Best Pract Res Clin Endocrinol Metab 2008; 22:941-953.

31 Cheung K, Roman SA, Wang TS, Walker HD, Sosa JA: Calcitonin measurement in the evaluation of thyroid nodules in the United States: a cost-effectiveness and decision analysis. J Clin Endocrinol Metab 2008;93:2173-2180.

- 32 Akan B, Böhmig G, Sunder-Plassmann G, Borchhardt KA: Prevalence of hypercalcitoninemia in patients on maintenance dialysis referred to kidney transplantation. Clin Nephrol 2009;71:538-542.

- 33 Borchhardt KA, Hörl WH, Sunder-Plassmann G: Reversibility of 'secondary hypercalcitoninemia' after kidney transplantation. Am J Transplant 2005;5:1757-1763.

-34 Karam M, Gianoukakis A, Feustel PJ, Cheema A, Postal ES, Cooper JA: Influence of diagnostic and therapeutic doses on thyroid remnant ablation rates. Nucl Med Commun 2003;24: 489-495.

35 Leboeuf R, Langlois MF, Martin M, Ahnadi CE, Fink GD: 'Hook effect' in calcitonin immunoradiometric assay in patients with metastatic medullary thyroid carcinoma: case report and review of the literature. J Clin Endocrinol Metab 2006;91:361-364.

-36 Preissner CM, Dodge LA, O’Kane DJ, Singh RJ, Grebe SK: Prevalence of heterophilic antibody interference in eight automated tumor marker immunoassays. Clin Chem 2005;51: 208-210. 